\title{
Snacks and the City
}

\section{Hoe een veldexperiment naar gezond snacken onze aannamen over de juiste snack op de juiste plaats op de proef stelt}

\author{
Denise de Ridder · Caroline Schlinkert · Marleen Gillebaart · Maartje Poelman · Jeroen Benjamins
}

(C) The Author(s) 2020

Samenvatting Veel mensen willen graag gezond snacken, maar vinden het lastig om dit voornemen in de praktijk te brengen. Dat komt omdat ze voortdurend geconfronteerd worden met ongezonde snacks als ze op weg zijn naar school, werk of andere activiteiten. In het project Food in Motion hebben we onderzocht of gezond snacken gemakkelijker wordt door het aanbieden van aantrekkelijke en toch gezonde snacks op tijden en plaatsen waar mensen geregeld ongezond snacken. Met het global positioning system (GPS) hebben we eerst in kaart gebracht wat 'gevaarlijke' tijden en plaatsen zijn voor ongezond snacken. Vervolgens is op basis van een groot onderzoek onder meer dan duizend mensen een nieuwe aantrekkelijke snack ontwikkeld, die voldeed aan de richtlijnen voor gezonde voeding. Deze snack (een klein fruit- of groentetaartje) werd gedurende drie maanden aangeboden vanuit een kleine food truck op het stationsplein in Utrecht. De verkoopcijfers vielen tegen, ondanks de grote waardering van het publiek voor de snack en de gekozen plek om te verkopen. We geven een aantal mogelijke verklaringen voor de tegenvallende verkoopcijfers.

Trefwoorden obesogene omgeving · gezonde snacks · food truck · gezondheidsbeleid

D. de Ridder $(\bowtie) \cdot$ C. Schlinkert · M. Gillebaart · J. Benjamins Afdeling Sociale Gezondheid en Organisatie Psychologie, Universiteit Utrecht, Utrecht, Nederland d.t.d.deridder@uu.nl

M. Poelman

Leerstoelgroep Consumptie en Gezonde Leefstijl,

Universiteit Wageningen, Wageningen, Nederland

\section{Snacks and the City Findings from a field experiment on healthy snacking challenge assumptions about the right snack at the right spot}

Abstract Many people hold the intention to consume fewer unhealthy snacks, but experience difficulties in acting upon it because their food environment confronts them with many unhealthy snacking opportunities when navigating the city on their way to work or school. In the Food in Motion research project we examined whether healthy snacking is easier when healthy snacks are available at spots where people tend to consume unhealthy snacks. We first determined by Global Positioning System (GPS) the critical places where people engage in unhealthy snacking. Next, we elicited associations with 'ideal snacks' in a large community sample to identify relevant features for the design of a new attractive snack that would be appreciated by the target population and meet the nutritional requirements for healthy food. The new snack (a small vegetable or fruit pie low in sugar, fat and salt) was sold from a small food truck for a period of three months at the railway station where people habitually consume unhealthy snacks. Despite positive responses to the new snack as well as to the place where it was sold, sales were below expectations. Our discussion identifies a number of reasons that might explain why few people bought the new snack.

Keywords obesogenic environment · healthy snacking · food truck · public health policy

\section{Inleiding}

Veel mensen hebben een ongezond eetpatroon, dat zich kenmerkt door een hoge consumptie van voedsel dat rijk is aan vet, suiker en zout, en een lage con- 
sumptie van groente en fruit [1]. Ongezond eten, samen met te weinig bewegen, kan leiden tot overgewicht en andere gezondheidsklachten [1]. Een grote boosdoener in een ongezond eetpatroon is het consumeren van ongezonde snacks tussen de maaltijden door [2, 3]. Schattingen laten zien dat zo'n 25 tot 35\% van de dagelijks geconsumeerde calorieën (om en nabij de 600 calorieën) afkomstig is van snacks en dat het aantal mensen dat dagelijks drie of meer ongezonde tussendoortjes tot zich neemt sinds de jaren zeventig van de vorige eeuw verviervoudigd is [4-6]. Niet alleen eten mensen vaker snacks, ook eten ze er grotere porties van [7].

Pogingen om mensen met voorlichtingscampagnes gezonder te laten snacken hebben tot dusver weinig vruchten afgeworpen [1]. De zogeheten obesogene voedselomgeving, waarin calorierijke en goedkope snacks op veel plekken en op alle tijden van de dag in ruime mate voorhanden zijn, maakt het ook voor mensen die minder willen snacken lastig om te ontsnappen aan het overweldigende aanbod [8, 9]. Bovendien snacken mensen vaak op de automatische piloot, zonder te bedenken of ze de snack ook echt willen [10]. Voor zover er gezonde snacks worden aangeboden, zijn mensen minder snel geneigd die te kopen omdat ze 'gezond' vaak associëren met 'minder lekker' en al helemaal als ze het gezonde alternatief als een opgelegde keuze ervaren [11, 12].

Maar wat vinden mensen van gezonde snacks als ze niet worden opgedrongen? Als het gaat om gezonde snacks die er lekker uitzien en bovendien gemakkelijk te verkrijgen zijn? Dat zijn de vragen die centraal staan in het Food in Motion-onderzoeksproject - in het Nederlands Op de Gezonde Toer (https://degezondetoer. $\mathrm{nl} /$ ). In dit project onderzochten we of het aanbieden van gezonde én smakelijke snacks op plekken waar mensen gewend zijn ongezond te snacken de gezonde keuze makkelijker maakt.

Het experiment had twee uitgangspunten. Ten eerste wilden we de gezonde keuze makkelijker maken door gezonde snacks aan te bieden op hotspots waar mensen vaak snacken maar het aanbod vrijwel uitsluitend uit ongezonde snacks bestaat. Het makkelijker en aantrekkelijker maken van goede keuzen is het uitgangspunt van nudging, waarbij mensen gestimuleerd worden om gezond te eten zonder het ongezonde alternatief onmogelijk te maken [13]. De meeste nudging-interventies bestaan uit aanpassingen in de keuzecontext door bijvoorbeeld in de supermarkt een sociale norm bij de meer gezonde (vetarme) kaas te plaatsen ('favoriet bij onze klanten') of door in een perronkiosk op het treinstation fruit en gezonde repen als kassakoopje aan te bieden om die zo prominenter onder de aandacht te brengen [14-16]. Een recente meta-analyse laat zien dat dit soort interventies effectief is in het bevorderen van gezondere aankopen [17]. In het Food in Motion experiment gingen we nog een stap verder door het gezonde alternatief aan te bieden op specifieke tijden en plaatsen die berucht zijn vanwege een hoge consumptie van ongezonde snacks. Dat deden we door een nieuwe gezonde en aantrekkelijke snack aan te bieden vanuit een kleine mobiele food truck, waardoor we de mogelijkheid hadden om nog dichter bij de specifieke plek te komen waar de ongezonde keuze meestal plaatsvindt.

Het tweede uitgangspunt van Food in Motion was om het gezonde alternatief aantrekkelijk te maken door het niet al te nadrukkelijk als gezond te afficheren, omdat dit mogelijk associaties met 'minder lekker' oproept [11]. Onze ambitie was om een gezonde snack aan te bieden die er vooral lekker uitziet en niet direct associaties oproept met een 'verstandige keuze' om gezond te eten. Dat deden we door met de input van de doelgroep een nieuwe snack te ontwerpen die in hun ogen 'ideaal' was.

In dit artikel doen we verslag van dit ambitieuze experiment, waarmee we probeerden aan te tonen dat een gezonde leefomgeving in de vorm van het toegankelijker maken van gezonde lekkere snacks kan bijdragen aan een hogere consumptie van die snacks. Doel van het Food in Motion-project was om een aantrekkelijke snack te verkopen op een plek waar mensen gewend zijn ongezond te snacken om het zo voor hen gemakkelijker te maken om onderweg gezond te snacken. Het gehele experiment bestond uit verschillende deelonderzoeken. Eerst brachten we in kaart op welke tijden en plaatsen mensen snacken als ze on the go zijn. Vervolgens gingen we na aan welke eisen een ideale snack zou moeten voldoen. Daarna onderzochten we of het aanbieden van deze 'ideale' snack op kritieke tijden en plaatsen ook snackgedrag veranderde, dat wil zeggen of mensen deze gezonde snacks daadwerkelijk kochten en of hun mening over gezond snacken veranderde. We kunnen nu alvast verklappen dat dit niet het geval was, wat belangrijke vragen oproept over gangbare aannamen over de rol van de (on)gezonde leefomgeving in snackconsumptie, die gedreven worden door het idee dat het aanbod de vraag schept.

\section{Methode}

Het experiment bestond uit drie onderdelen. Ten eerste hebben we mensen met GPS en een snack-app gevolgd om in kaart te brengen waar en wanneer ze ongezonde snacks eten, met als doel om een of meer locaties te bepalen waar we het gezonde alternatief zouden aanbieden. Het tweede onderdeel betrof een groot onderzoek naar de associaties die mensen hebben met ideale snacks, met als doel om een aantrekkelijke snack te ontwerpen die voldeed aan criteria van lekker en gezond. Op basis van deze gegevens heeft een food designer een nieuwe snack ontworpen die voldeed aan de eisen die gelden voor gezonde voeding volgens de richtlijnen van het Voedingscentrum, maar die er tegelijkertijd smakelijk uitzag door uiterlijk en branding. In het derde onderdeel van het experiment gingen we na of het aanbieden van de nieuwe 


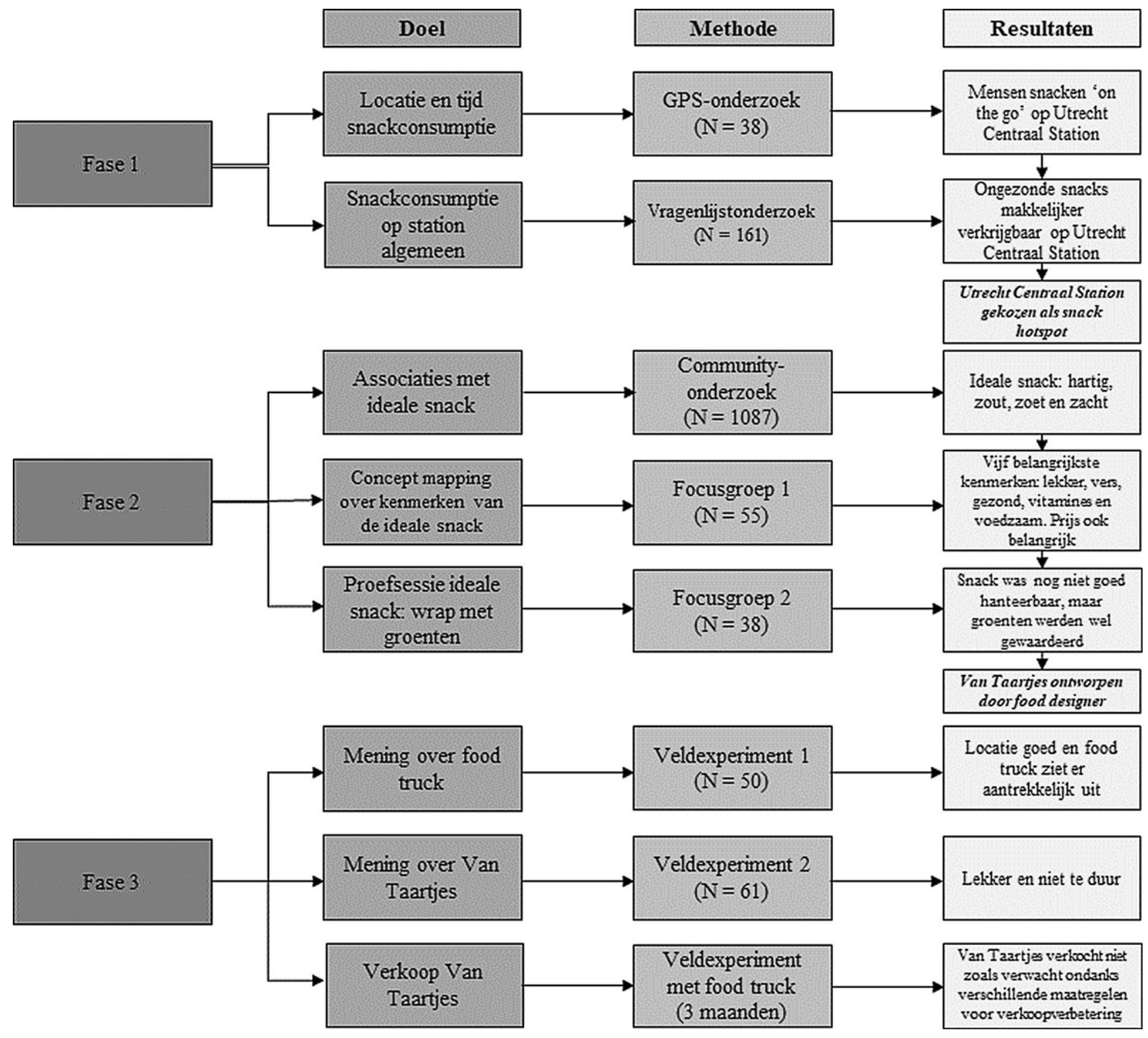

Figuur 1 Overzicht van alle Food in Motion-onderzoeken

snack met een food truck op de plek die in het eerste deel van het experiment naar voren was gekomen, zou leiden tot een hogere consumptie van gezonde snacks (afgemeten aan de verkoopcijfers). In alle fasen van het experiment zijn uitdrukkelijk ook mensen met een lage sociaaleconomische status betrokken, omdat eerder onderzoek heeft aangetoond dat zij vaker overgewicht hebben $(65 \%)$ dan mensen met een hogere sociaaleconomische status $(40 \%)$, ondanks hun voornemen om gezonder te leven $[18,19]$. Figuur 1 geeft een overzicht van alle onderzoeken van het Food in Motion-project.

\section{Resultaten}

\section{Waar en wanneer consumeren mensen snacks?}

Er wordt vaak gesuggereerd dat het merendeel van de snackconsumptie buitenshuis plaatsvindt terwijl mensen onderweg zijn en mogelijk in de verleiding komen om iets te kopen op een van de vele plekken waar snacks worden aangeboden [20, 21]. Om te kijken welke plekken favoriet zijn, hebben we een groep mensen $(n=38)$ drie dagen lang gevolgd met een snackdagboek-app, terwijl GPS de tijd en plaats 


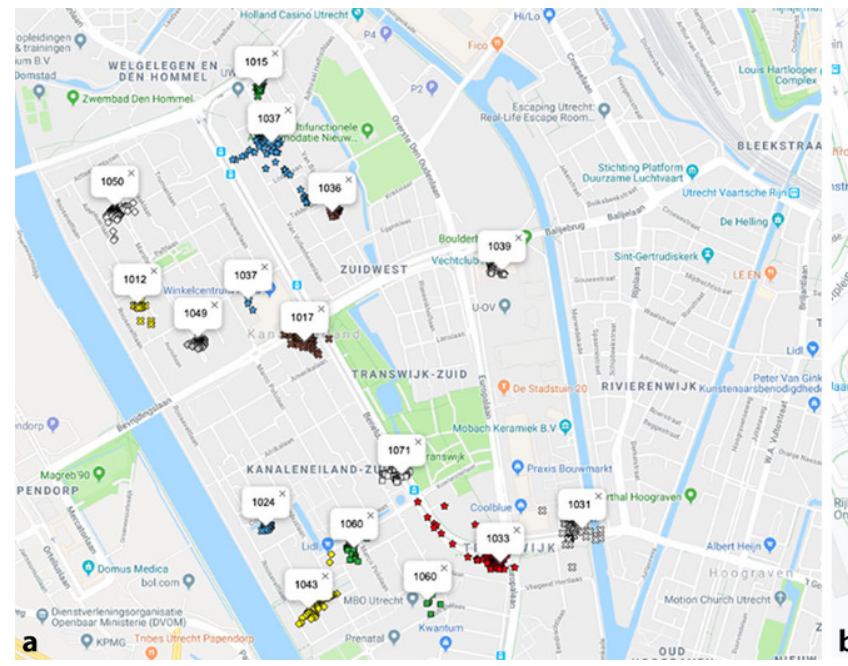

Figuur 2 GPS-data van snackconsumptie. Figuur $\mathbf{2 a}$ betreft unieke personen die snacks thuis in de wijk Kanaleneiland consumeren. Figuur $\mathbf{2 b}$ toont het cluster station Utrecht Cen-

van hun consumptie vastlegde. ${ }^{1}$ Hieruit bleek dat het merendeel van de snacks, anders dan wordt gedacht, thuis wordt gegeten (fig. 2a). Dit sluit aan bij de bevindingen uit een recent onderzoek dat laat zien dat mensen vooral thuis $(58 \%)$ of op het werk $(23 \%)$ snacken [22]. Een belangrijke reden voor thuisconsumptie van snacks, genoemd door de groep mensen die wij hebben gevolgd, is dat snacken buitenshuis duur is. Liever kopen ze om die reden snacks bij de supermarkt, die ze vervolgens thuis opeten. Voor zover mensen buitenshuis snacken is dat niet in hun eigen wijk, maar op plekken waar ze ver van huis zijn en dus niet de mogelijkheid hebben om thuis te snacken. Het station bleek in ons onderzoek de plek waar het vaakst buitenshuis wordt gesnackt (fig. 2b), en als zodanig een goede plek om gezonde snacks als alternatief aan te bieden.

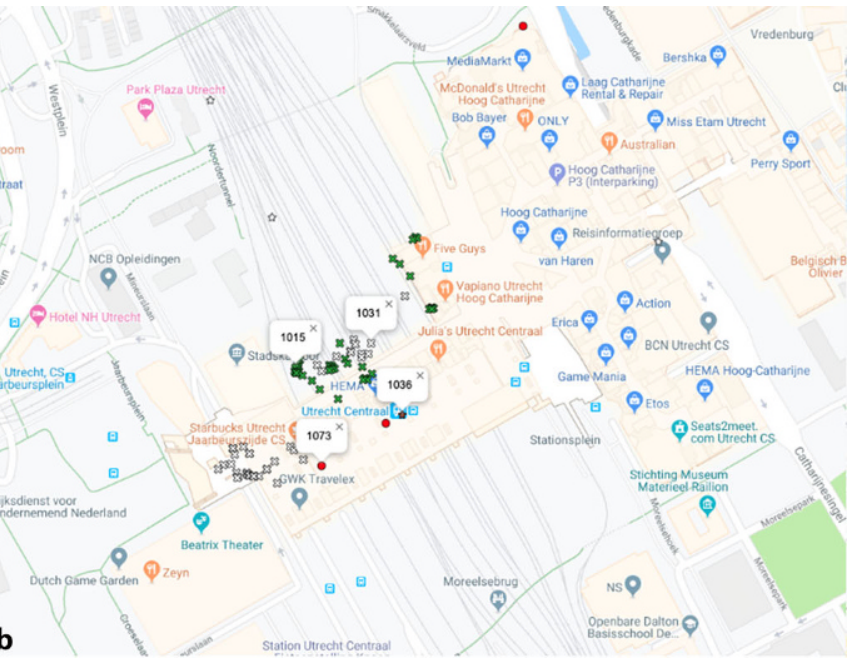

traal, met een radius van 300 meter die minimaal twee unieke personen betreft

\section{Op zoek naar de ideale snack}

De volgende vraag was welke gezonde snacks er op deze hotspot zouden moeten worden aangeboden. Eerder onderzoek heeft aangetoond dat mensen vaker ongezonde dan gezonde snacks nuttigen [23]. Maar betekent dit ook dat mensen echt een voorkeur hebben voor ongezonde snacks of is ongezonde snackconsumptie eerder het gevolg van het ontbreken van voldoende smakelijke gezonde alternatieven? Met andere woorden: denken mensen bij snacks automatisch aan producten die volgens de geldende maatstaven ongezond zijn - met veel suiker, zout en/of vet -, of noemen ze ook uit zichzelf eigenschappen of producten die voor gezond doorgaan? Om dit na gaan vroegen we een grote groep mensen $(n=1.087)$ naar hun spontane associaties met een 'ideale snack'. De resultaten van dit onderzoek zijn elders uitgebreid beschreven, maar komen in het kort op het volgende neer [24]. Op de vraag waar mensen bij een ideale snack aan denken, noemen ze het vaakst eigenschappen als warm, zoet, koud, hartig en gezond (fig. 3). 'Gezond' staat dus in de top 5 van meest genoemde eigenschappen van de ideale snack, terwijl typische kenmerken van ongezonde snacks als 'zout' of 'vullend' veel minder vaak werden genoemd. Als het gaat om specifieke producten die de deelnemers als ideale snack noemen zijn het vaak gezondere snacks, zoals broodjes (vaak expliciet benoemd als 'broodje gezond'), fruit en graanrepen (samen $31 \%$ van alle genoemde producten), en veel minder vaak typisch ongezonde producten als chocolade en koek (samen 14\%) (fig. 4). Uit deze cijfers komt naar voren dat mensen geenszins bezwaren hebben tegen gezonde snacks als ideaal tussendoortje. Integendeel, uit de antwoorden blijkt dat hun ideale snack vaak overeenkomt met een gezonde snack of de typische kenmerken heeft van een gezonde snack. Relevant is 


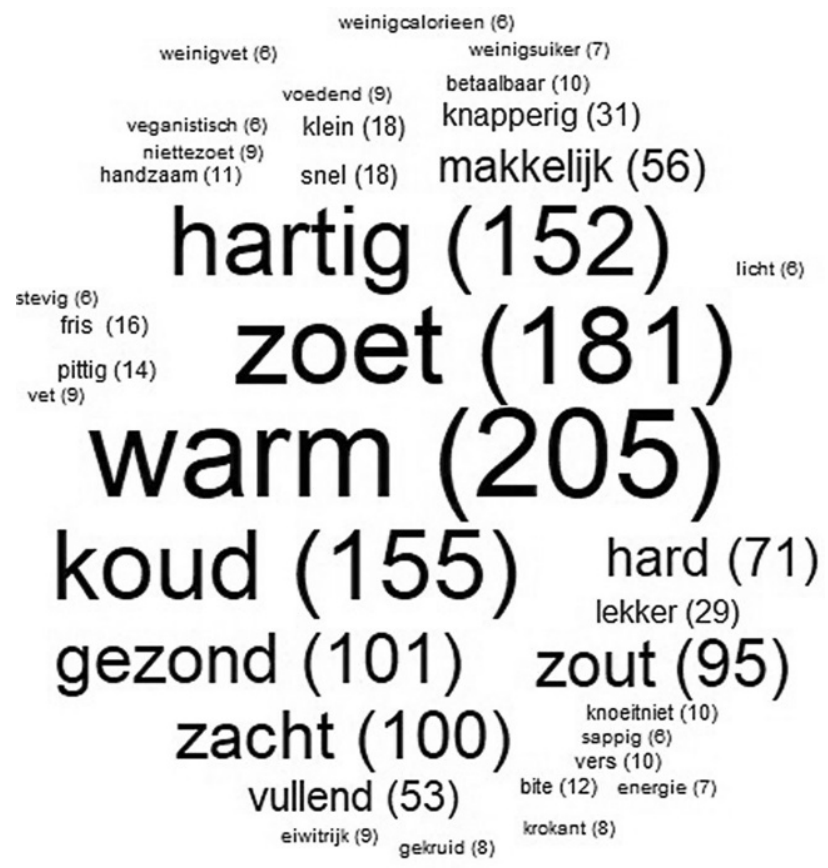

Figuur 3 Frequenties van woordassociaties bij eigenschappen van de ideale snack $(n=1.087)$. Tussen haakjes staat het aantal keer dat de betreffende eigenschap is genoemd (in totaal werden 1.450 responsen gegeven)

ook dat het de deelnemers niet zoveel uitmaakt of de snack warm of koud is en ook niet of het gaat om een zoete dan wel hartige snack. Beide worden ongeveer even vaak genoemd.

Om erachter te komen hoe zo'n warme/koude of hartige/zoete gezonde snack er precies uit zou moeten zien, hebben we focusgroepen georganiseerd waarin we mensen de vraag voorlegden wat ze lekker en gezond vinden om onderweg te eten, met de genoemde kenmerken in het achterhoofd. De antwoorden suggereerden dat een groentewrap een mogelijke optie is, maar ook als lastig te hanteren werd gezien, zeker als ze deze zouden moeten opeten als ze onderweg waren. Op basis van al deze gegevens is een food designer aan de slag gegaan, die een taartje heeft ontwikkeld dat voldoet aan de richtlijnen voor gezonde voeding (groente- of fruitvulling; een bodem van volkorenmeel met weinig zout en vet, en zonder toegevoegde suiker), ${ }^{2}$ maar tegelijkertijd een aantrekkelijke en smakelijke uitstraling heeft. De conceptversie van deze taartjes is voorgelegd aan een groep van 38 mensen om op smaak en presentatie te beoordelen. Op een schaal van 1 (helemaal niet lekker/aantrekkelijk) tot 5 (heel erg lekker/aantrekkelijk) werden de taartjes als tamelijk aantrekkelijk (gemid-

2 De receptuur Van Taartjes is als volgt. Taartbodem: $20 \mathrm{~g}$ volkorenbloem, 0,23g zout, $10 \mathrm{~g}$ margarine, $1,36 \mathrm{~g}$ ijswater. Hartige Ratatouillevulling: $6 \mathrm{~g}$ ui, 2,4g olijfolie, $0,2 \mathrm{~g}$ knoflook, $32 \mathrm{~g}$ courgette, $6,4 \mathrm{~g}$ rode paprika, $13 \mathrm{~g}$ tomaat, $0,06 \mathrm{~g}$ zout, Provençaalse kruiden. Zoete vulling: 53,2g appel, 6,6g rozijnen, 0,07g kaneel.

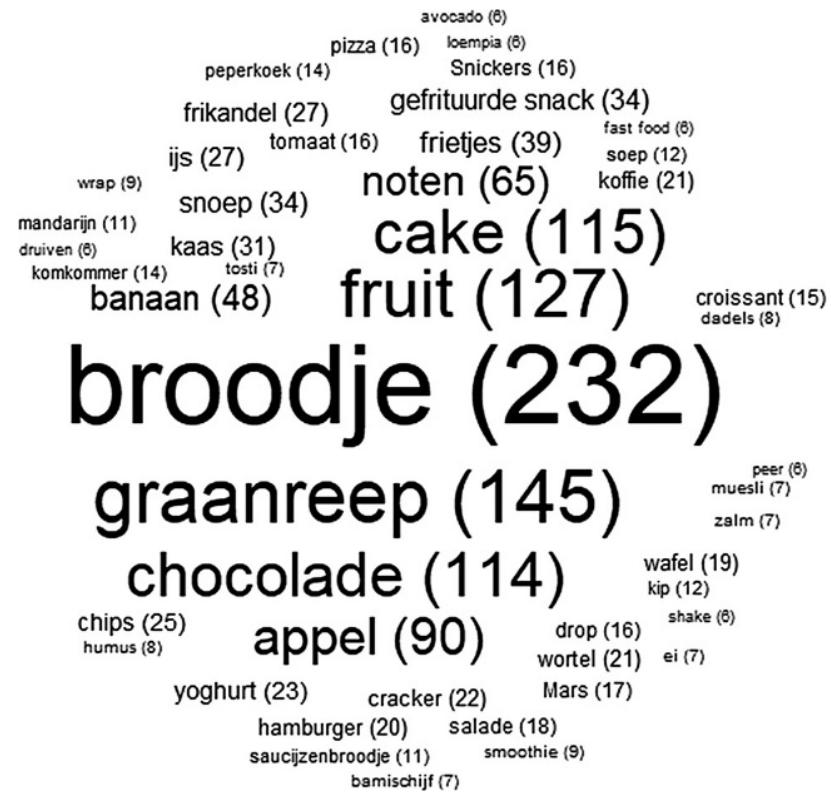

Figuur 4 Frequenties van woordassociaties bij het ideale snackproduct $(n=1.087)$. Tussen haakjes staat het aantal keer dat het betreffende snackproduct is genoemd (in totaal werden 1.680 responsen gegeven)

delde $($ gem $)=3,8$, standaarddeviatie $(\mathrm{sd})=0,43$ ) en redelijk smakelijk (gem $=3,2$, sd $=0,94$ ) beoordeeld. Ook vonden mensen dat ze er gezond uitzagen ( $\mathrm{gem}=4,2$, $\mathrm{sd}=0,38$ ) en gaven ze aan dat ze deze taartjes wel zouden willen kopen $(m=3,23$, sd=0,94). Na een aantal kleine aanpassingen in de receptuur is het uiteindelijke product gebrand als Van Taartjes. De food truck van waaruit de taartjes werden verkocht (een Piaggio) werd net als het menu in dezelfde stijl gebrand (fig. 5, 6 en 7).

\section{Consumeren mensen vaker gezonde snacks als deze makkelijk verkrijgbaar zijn?}

Alvorens de food truck daadwerkelijk op het stationsplein te plaatsen, is een onderzoek gedaan onder mensen die regelmatig met de trein reizen $(n=161)$ door hen op het station te vragen naar hun snackconsumptie. Hieruit bleek dat veel treinreizigers (68\%) met grote regelmaat snacks kochten op het station, waarbij ze van mening waren dat ongezonde snacks heel gemakkelijk (44\%) en gezonde snacks juist niet gemakkelijk verkrijgbaar zijn (23\%). Bijna de helft $(47 \%)$ van de ondervraagden gaf bovendien aan een groter aanbod aan gezonde snacks in het stationsgebied op prijs te stellen.

Vervolgens is de food truck in het voorjaar van 2019 gedurende drie maanden op het stationsplein geplaatst, tijdens werkdagen van 14 tot 18 uur (zie voor film, foto's en promotiemateriaal https:// degezondetoer.nl/). De verkoopcijfers vielen tegen: gemiddeld werden zo'n vijf taartjes per dag verkocht. Maatregelen om de verkoop te bevorderen, zoals een prijsverlaging van $€ 2,50$ (een bedrag dat aan de lage 


\section{Wetenschappelijk artikel}

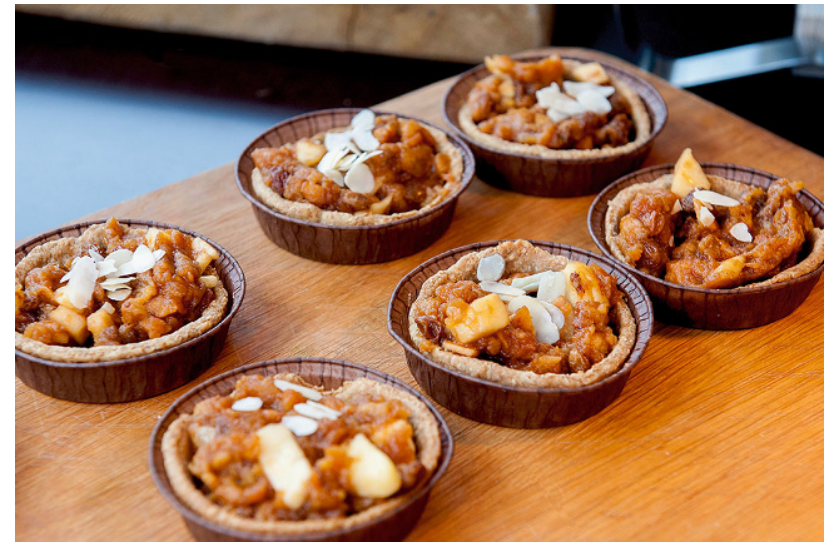

Figuur 5 De zoete variant van de Van Taartjes-snack

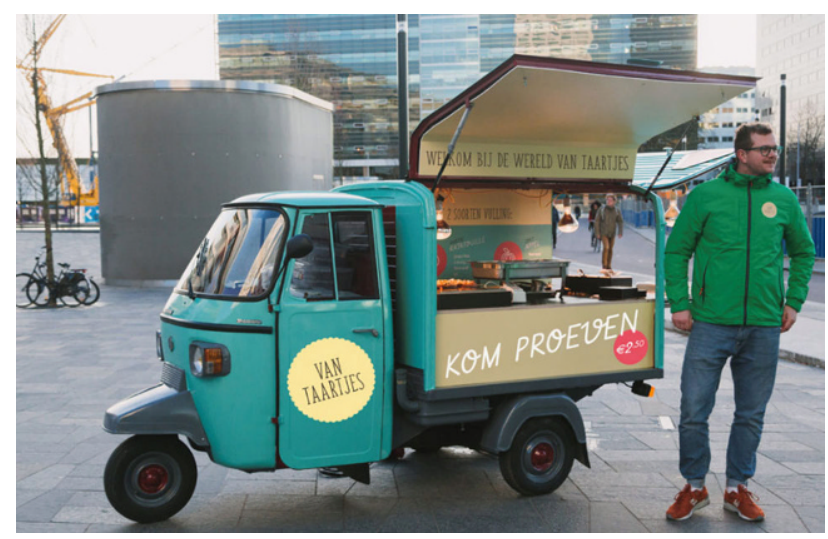

Figuur 6 Design van de food truck

kant is vergeleken met de gemiddelde prijs die op het station voor een snack betaald moet worden) naar $€ 1,75$ (een bedrag dat overeenkomt met de prijs van favoriete producten op het station, zoals een kroket of een appelflap) leidde niet tot meer verkochte taartjes.

Aanvankelijk werd Van Taartjes aangeboden zonder expliciet te melden dat het om een snack ging die voldeed aan de richtlijnen voor gezonde voeding. Het expliciet aanprijzen van de snack als gezond, om potentiële klanten een extra argument te geven om de snack te kopen, had geen invloed op de verkoop. Ook het gratis aanbieden van een stukje taart om te proeven of een social proof-experiment, waarbij een rij van wachtenden (handlangers van de onderzoekers) voor de food truck werd gevormd om belangstelling aan te wakkeren, leidde niet tot een stijging van de verkoop.

Opvallend was dat veel potentiële klanten de food truck voorbij liepen zonder acht te slaan op wat er precies verkocht werd. Dit suggereert dat een negatief oordeel over de taartjes niet de voornaamste reden was voor de geringe belangstelling. Eerder leken reizigers niet te verwachten dat ze bij de food truck snacks konden kopen. Toch liet een onderzoek onder reizigers $(n=50)$ die zich in de buurt van de truck bevonden zien dat ze de locatie van de truck goed gekozen vonden (gem $=5,5, \mathrm{sd}=1,8$ ) en de food truck er

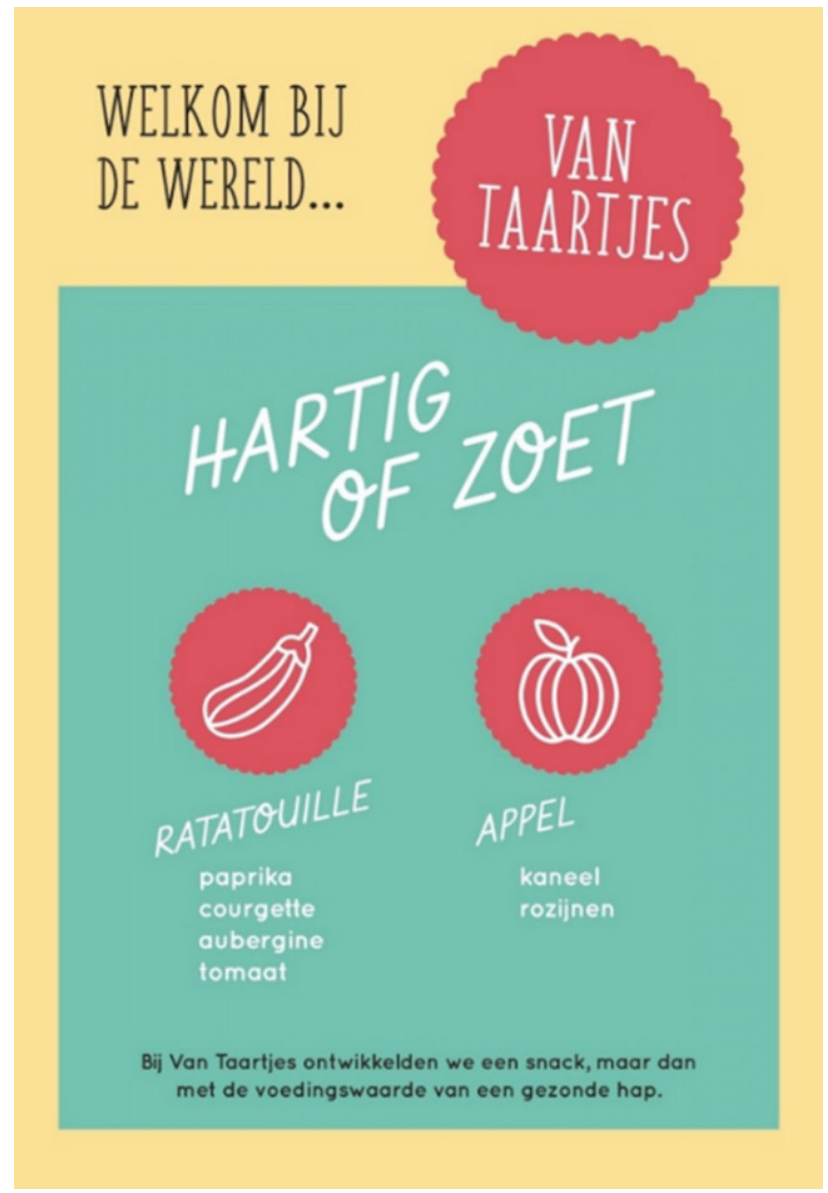

Figuur 7 De Van Taartjes-menukaart

aantrekkelijk vonden uitzien (gem $=6,2$, $s d=1,0$ ). Ook en opnieuw vonden ze de taartjes er lekker (gem $=5,5$, $\mathrm{sd}=1,1)$ en gezond ( $\mathrm{gem}=5,9, \mathrm{sd}=1,3$ ) uitzien. Aan 61 klanten die daadwerkelijk een Van Taartje hadden gekocht, hebben we gevraagd wat ze vonden van de smaak en de prijs. Hieruit bleek dat ze de snack lekker vonden (gem $=4,5, \mathrm{sd}=1,4)$ en niet te duur ( $\mathrm{gem}=3,4$, $s d=1,6$ ). Alle vragen zijn beantwoord op een zevenpuntsschaal.

Alles samengenomen laat ons experiment zien dat het aanbieden van lekkere en gezonde snacks op een hotspot waar mensen gewend zijn ongezond te snacken niet leidt tot een verandering in snackgedrag, in de zin dat treinreizigers niet gebruikmaakten van de mogelijkheid om een gezonde snack te kopen bij de Van Taartjes-food truck. Dit gegeven is opmerkelijk omdat veel potentiële klanten hadden aangegeven een gezond alternatief op prijs te stellen. De grote vraag is dus wat hier precies aan de hand is. We laten een aantal mogelijke verklaringen de revue passeren.

\section{Beschouwing}

Het Food in Motion-project kwam voort uit de gedachte dat de obesogene omgeving voor een belangrijk deel onze voedselkeuzen dicteert [25]. Door de 
alomtegenwoordige aanwezigheid van ongezond eten en het ontbreken van gezonde alternatieven zijn mensen als het ware gedoemd om onderweg ongezonde snacks te kopen, zelfs als ze dat liever niet zouden willen. Door een gezond alternatief prominent aan te bieden en bovendien aantrekkelijker te maken - beter gezegd: door het überhaupt aan te bieden -, worden mensen in de gelegenheid gesteld om een keuze te maken tussen gezond en ongezond. Gezien de resultaten van ons project is dit een te simpele voorstelling van zaken gebleken. De keuze voor gezond maakten we misschien wel makkelijker en aantrekkelijker, maar kennelijk was dat onvoldoende om van de gezonde snack een vanzelfsprekende keuze te maken.

Twee mogelijke verklaringen voor dit resultaat liggen voor de hand, maar zijn niet erg waarschijnlijk: de prijs en de gezonde uitstraling van de nieuwe snack. Vaak wordt geopperd dat gezond eten duur is en te duur voor mensen die het niet breed hebben. De prijs voor een Van Taartje was echter conform (en zelfs aan de lage kant vergeleken met) de prijzen die voor een gemiddelde snack in het stationsgebied betaald moeten worden. Wat betreft de gezonde uitstraling van de snack: veel mensen vonden de snack er gezond uitzien, maar bij de verkoop werd hier niet speciaal op geattendeerd vanwege het idee dat mensen om die reden de snack mogelijk minder aantrekkelijk zouden vinden. Omdat we wilden onderzoeken of het label 'gezond' toch iets extra's zou bieden, hebben we de snack op enig moment wel als 'gezond' aangeprezen, maar dit bleek geen effect te hebben op de verkoop. Toch blijkt uit andere onderzoeken dat gezondheidsmotieven wel degelijk een rol spelen bij voedselkeuzen [26].

Er zijn ook nog andere verklaringen mogelijk voor de tegenvallende verkoopcijfers van de Van Taartjessnack, waarvan we het effect niet precies kunnen vaststellen. In ons onderzoek gaven veel mensen aan dat ze wel gezond(er) zouden willen snacken. Dat geldt zowel voor de deelnemers aan het onderzoek waarin ze de eigenschappen van hun ideale snack mochten benoemen, als voor de treinreizigers in het onderzoek die aangaven een groter aanbod van gezonde snacks op het station te appreciëren. Het zou echter kunnen dat mensen wel zeggen gezonder te willen snacken, maar dat dit eerder een vaag voornemen is dan een echt plan. In de psychologische literatuur wordt een onderscheid gemaakt tussen ought to (zou moeten) en want to (zou willen) motieven om een bepaalde keuze te maken [27]. Zou-moeten-motivatie lijkt op wat ook wel 'extrinsieke motivatie' wordt genoemd, waarbij mensen iets doen omdat dat van hen verwacht wordt, zonder dat ze er zelf helemaal achter staan. Ook wordt in de psychologische literatuur vaak een onderscheid gemaakt tussen fantaseren over hoe iemand zich zou willen gedragen - dagdromen zonder concrete stappen te zetten nemen om dit realiseren en een 'bindend doel', waar iemand zich ook echt voor wil inspannen [28]. Met deze bevindingen uit de psy- chologische literatuur in het achterhoofd, achten wij het mogelijk dat de deelnemers in ons onderzoek van mening zijn dat ze gezonder zouden moeten snacken, maar dit niet ervaren als een bindend doel dat ook stand houdt als ze voor de keuze staan om al dan niet een gezonde snack te kopen.

Een tweede mogelijke verklaring is dat mensen gewoontedieren zijn en alleen snacks kopen bij een outlet die ze al kennen en waar ze gewend zijn hun snacks te kopen. Deze verklaring is aannemelijk omdat veel mensen aan de food truck voorbijliepen zonder er aandacht aan te besteden, terwijl het om een opvallende en nieuwe verschijning ging, die prominent bij de ingang van het station geplaatst was (juist om concurrentie van reguliere snackoutlets te voorkomen). Ook vonden treinreizigers dat de food truck er leuk uitzag en achtten ze de locatie geschikt. Dit neemt echter niet weg dat ze mogelijk liever - zonder nadenken - de snack kopen die ze altijd kopen. Volgens gegevens van de NS komt daar nog bij dat veel treinreizigers pas rust hebben als ze zijn ingecheckt, en het moment om een snack te kopen en te eten uitstellen tot het moment dat ze zeker weten dat ze hun trein gaan halen.

Een derde verklaring zou kunnen zijn dat de Van Taartjes-food truck een te exclusief aanbod had dat louter uit de nieuwe taartjes bestond. De enige keuze die klanten hadden was een zoete of hartige variant van het taartje. Het kan zijn dat mensen zich beperkt voelden in hun keuze doordat er maar één type snack werd aangeboden. In het algemeen hechten mensen aan keuze en voelen ze zich beknot als er maar weinig opties zijn [29]. Als het inderdaad zo is dat het aanbieden van slechts één soort snack de behoefte aan keuze frustreert, zou het aanbeveling verdienen om de snack niet aan te bieden in een speciaal daarvoor ontworpen food truck, maar deze onder te brengen in het reguliere aanbod van snackoutlets op het station. ${ }^{3}$

Een laatste verklaring, die met de vorige samenhangt, is dat het aanbieden van een gezonde snack via één exclusief verkoopkanaal in een omgeving met een overvloed aan ongezonde snacks niet doeltreffend genoeg was om mensen te ondersteunen in het kopen van een gezonde snack. Ook om die reden verdient het aanbeveling om gezonde snacks prominenter onder te brengen in het reguliere aanbod op het station. Dit kunnen Van Taartjes zijn, maar nog beter zou het zijn om een grotere variëteit aan gezonde snacks aan te bieden om de gezonde keuze meer voor de hand liggend te maken.

Het meest waarschijnlijk is dat alle bovengenoemde verklaringen met elkaar samenhangen en elkaar zelfs

\footnotetext{
$3 \mathrm{Na}$ het afronden van het experiment met de food truck op het stationsplein is op het moment van schrijven van dit artikel een experiment gaande met het aanbieden van de Van Taartjes-snack in een van de reguliere snackoutlets op het station, waar de gezonde Van Taartjes-snack wordt aangeboden pal naast conventionele ongezonde snacks.
} 
versterken. Hoe het ook zij, de beschikbaarheid van een gezond snackalternatief dat er aantrekkelijk en smakelijk uitziet verdient verder onderzoek naar de manier waarop dit het beste onder de aandacht van consumenten gebracht kan worden en hen in de gelegenheid stelt om een snack te kopen waar ze naar eigen zeggen behoefte aan hebben als ze onderweg zijn.

Open Access This article is licensed under a Creative Commons Attribution 4.0 International License, which permits use, sharing, adaptation, distribution and reproduction in any medium or format, as long as you give appropriate credit to the original author(s) and the source, provide a link to the Creative Commons licence, and indicate if changes were made. The images or other third party material in this article are included in the article's Creative Commons licence, unless indicated otherwise in a credit line to the material. If material is not included in the article's Creative Commons licence and your intended use is not permitted by statutory regulation or exceeds the permitted use, you will need to obtain permission directly from the copyright holder. To view a copy of this licence, visit http://creativecommons.org/licenses/by/4.0/.

\section{Literatuur}

1. RidderDTDde, KroeseF, Evers C, AdriaanseM, GillebaartM. Healthy diet: health impact, prevalence, correlates, and interventions. Psychol Health. 2017;32:907-41.

2. Howarth NC, Huang TT, Roberts SB, Lin BH, McCrory MA. Eating patterns and dietary composition in relation to BMI in younger and older adults. Int J Obes. 2007;31:675-84.

3. Larson N, Story M. A review of snacking patterns among children and adolescents: what are the implications of snacking for weight status? Child Obes. 2013;9:104-15.

4. Cutler DM, Glaeser EL, Shapiro JM. Why have Americans become more obese? JEcon Perspect. 2003;17:93-118.

5. Piernas C, Popkin BM. Trends in snacking among US children. Health Aff. 2010;29:398-404.

6. Cleveland LE, Goldman JD, Moshfegh AM. Contribution of snacks to food and nutrient intakes in the United States. Fed AmSoc Exp Biol J. 2005;19:A88.

7. Kerr MA, Rennie KL, McCaffrey TA, Wallace JM, HannonFletcher MP, Livingstone MB. Snacking patterns among adolescents: a comparison of type, frequency and portion size between Britain in 1997 and Northern Ireland in 2005. BrJ Nutr. 2009;101:122-31.

8. Booth KM, Pinkston MM, Poston CWS. Obesity and the built environment. JAm Diet Assoc. 2005;105:110-7.

9. Ridder DTD de, Vet E de, Stok M, et al. Obesity, overconsumption and self-regulation failure: the unsung role of eating appropriateness standards. Health Psychol Rev. 2013;7:146-65.

10. Verhoeven AA, Adriaanse MA, Evers C, Ridder DT de. The power of habits: unhealthy snacking behavior is primarily predicted by habit strength. Br J Health Psychol. 2012;17:758-70.
11. Raghunathan R, Naylor RW, Hoyer WD. The unhealthy = tastyintuition andits effects on tasteinferences, enjoyment, and choice of food products. J Mark. 2006;70:170-84.

12. Finkelstein SR, Fishbach A. When healthy food makes you hungry. JConsum Res. 2010;37:357-67.

13. Thaler RH, Sunstein CS. Nudge. Improving decisions about health, wealth, and happiness. London: Penguin Books; 2008.

14. Salmon SJ, Vet E de, Adriaanse MA, et al. Social proof in the supermarket: promoting healthy choices under low selfcontrol conditions. Food Qual Pref. 2015;45:113-20.

15. Kroese FM, Marchiori DR, Ridder DTD de. Nudging healthy food choices: a field experiment at the train station. JPublic Health. 2015;38:e133-e7.

16. Gestel LC van, Kroese FM, Ridder DTD de. Nudging at the checkout counter-a longitudinal study of the effect of a food repositioning nudge on healthy food choice. Psychol Health. 2018;33:800-9.

17. Cadario R, Chandon P. Which healthy eating nudges work best? A meta-analysis of field experiments. Marketing Scie 2019. https://ssrn.com/abstract=3090829. Geraadpleegd op 10 januari 2020.

18. CBS, RIVM. Gezondheidsmonitor GGD'en. 2012.

19. Heutink H, Diemen D van, Elzenga M, et al. Wat hebben mensen met een lage en hoge(re) SES zelf te zeggen over gezond leven? Tijdschr Gezondheidswet. 2010;88:10-2.

20. Marshall D, Bell R. Meal construction: exploring the relationship between eating occasion and location. Food Qual Pref. 2003;14:53-64.

21. Nielsen SJ, Siega-Riz AM, Popkin BM. Trends in food locations and sources among adolescents and young adults. Prev Med. 2002;35:107-13.

22. Myhre JB, Løken EB, Wandel M, et al. The contribution of snacks to dietary intake and their association with eating location among Norwegian adults-results from a crosssectional dietary survey. BMCPublic Health. 2015;15:369.

23. Nørgaard MK, Sørensen BT, Brunsø K. A concept test of novel healthy snacks among adolescents: antecedents of preferences and buying intentions. Food Qual Pref. 2014;33:17-26.

24. Schlinkert C, Gillebaart M, Benjamins JS, Poelman M, Ridder D de. The snack that has it all: people's associations with ideal snacks. Appetite. 2020;152:104722.

25. Swinburn B, Egger G, Raza F. Dissecting obesogenic environments: the developmentand application of a framework for identifying and prioritizing environmental interventions for obesity. Prev Med. 1999;29:563-70.

26. Grunert KG, Wills JM. A review of European research on consumer response to nutrition information on foodlabels. JPublic Health. 2007;15:385-99.

27. Higgins ET. Making a good decision: value from fit. Am Psychol. 2000;55:1217-30.

28. Oettingen G, Pak H, Schnetter K. Self-regulation of goal setting: turning free fantasies about the future into binding goals. J Pers Soc Psychol. 2001;80:736-53.

29. Zuckerman M, Porac JF, Lathin D, et al. On the importance of self-determination for intrinsically motivated behavior. Pers Soc Psychol Bull. 1978;4:443-6. 